\title{
Composition of Cell Walls of Some Gram-Negative Cocci
}

\author{
BY R. K. GRAHAM AND J. W. MAY \\ Department of Microbiology, University of Western Australia, \\ Perth, Western Australia
}

(Received 31 May 1965)

\begin{abstract}
SUMMARY
Cell walls isolated from six species of Neisseria contained 17 amino acids, $6 \cdot 3-8 \cdot 3 \%$ mucopeptide, and $11 \cdot 4-30 \cdot 0 \%$ lipid. Veillonella parvula cell walls were similar, differing principally in the presence of $24.5 \%$ mucopeptide. The mucopeptide of all seven Gram-negative cocci contained glucosamine, muramic acid, glutamic acid, alanine, glycine and DL-diaminopimelic acid as principal components; the mucopeptide from $V$. parvula cell walls also contained an unidentified ninhydrin-reacting component. The marked similarity of the cell walls of the Gram-negative cocci and those of Gram-negative bacilli indicates a closer relationship between these two groups than between the Gram-negative and Grampositive cocci.
\end{abstract}

\section{INTRODUCTION}

On the basis of progressive changes in several properties, Bisset (1959) arranged the following genera of Gram-positive and Gram-negative cocci in a supposed phylogenetic series which started with Sarcina, passed through Micrococcus and Staphylococcus to Neisseria, and terminated with Veillonella. In an attempt to avoid relating two such distinct groups as the Gram-positive and Gram-negative bacteria, he claimed that Neisseria and Veillonella were only superficially Gramnegative (Bisset, 1959, 1962). In view of the marked chemical and structural differences between the cell walls of Gram-positive and Gram-negative bacteria (Salton, 1960; see also Murray, 1962; Perkins, 1963) Bisset's claim implies that the cell walls of Neisseria and Veillonella would be of the Gram-positive type. However, apart from data on the presence of lipid and amino sugar in the cell walls of Neisseria catarrhalis (Salton, 1963), little information is available on the chemical composition of the cell walls of Gram-negative cocci. We therefore examined some of the more important components of cell walls isolated from Veillonella parvula and six species of Neisseria.

\section{METHODS}

Organisms and growth conditions. Veillonella parvula no. 10,790 and Sarcina lutea no. 9341 were obtained from the American Type Culture Collection. Neisseria animalis no. 10,212, $N$. catarrhalis no. $3622, N$. caviae no. 10,293, $N$. flavescens no. 8263, N. pharyngis no. 4591, N. pharyngis-flavus no. 4590, Staphylococcus saprophyticus no. 7291 and Micrococcus lysodeikticus no. 2665 were obtained from the National Collection of Type Cultures (Colindale, London). Escherichia coli CL 30 was obtained from Dr B.A. D. Stocker and $E$. coli 173-25, auxotrophic for LLor DL-diaminopimelic acid (Davis, 1952; Hoare \& Work, 1955), from Dr J. Leder- 
berg. The bacteria were stored as lyophilized cultures (Annear, 1962) and maintained on meat infusion agar (Mackie and McCartney's Handbook, 1960) supplemented, where necessary, with $10 \%(v / v)$ defibrinated horse blood or diaminopimelic acid $10 \mu \mathrm{g} . / \mathrm{ml}$.

Veillonella parvula was grown anaerobically (McIntosh and Fildes jar) at $37^{\circ}$ for $18-24 \mathrm{hr}$ in $100 \mathrm{ml}$. batches of a modification of the medium of Rogosa (1956) which contained per litre: Trypticase (Baltimore Biological Laboratory Inc.), 10 g.; yeast extract (Baltimore Biological Laboratory Inc.), 5 g.; sodium lactate $(85 \%), 10 \mathrm{~g}$. All other bacteria were grown at $37^{\circ}$ for $18-24 \mathrm{hr}$ in $400 \mathrm{ml}$. batches of meat infusion broth (supplemented with $10 \%(\mathrm{v} / \mathrm{v})$ horse serum for Neisseria animalis, N. pharyngis and N. pharyngis-flavus) in 1-1. Erlenmeyer flasks on a reciprocal shaker (Kantorowicz, 1951).

Isolation of cell roalls. Bacteria were harvested in a refrigerated centrifuge and washed three times with cold distilled water. Portions (5-10 g.) of packed wet bacteria and 10-25 g. glass beads (Ballotini no. 12) were placed in the capsule of a cell disintegrator (Nossal, 1953) and shaken for three $1 \mathrm{~min}$. periods, the capsule being cooled in ice-water between runs. Phase-contrast microscopy showed that almost all the bacteria were broken by this treatment. The capsule was washed out with $50 \mathrm{ml}$. cold distilled water and the supernatant fluid decanted after the glass beads had settled. The beads were washed three times with distilled water and the combined washings centrifuged at $2000 \mathrm{~g}$ for $20 \mathrm{~min}$. to remove unbroken bacteria, steel particles and other debris. The supernatant fluid was centrifuged at $20,000 \mathrm{~g}$ for $15 \mathrm{~min}$. and the deposited cell walls washed three times with distilled water, frozen and dried in vacuo over $\mathrm{P}_{2} \mathrm{O}_{5}$.

Preparation of mucopeptide fraction. The mucopeptide fraction of the cell wall was isolated by a modification of the method of Schocher, Bayley \& Watson (1962). Lyophilized cell walls were suspended in $20 \%(\mathrm{w} / \mathrm{v})$ sodium dodecyl sulphate and incubated at $37^{\circ}$ for $18 \mathrm{hr}$, with gentle shaking. The suspension was centrifuged at $20,000 \mathrm{~g}$ for $30 \mathrm{~min}$., and the deposited mucopeptide fraction freed from sodium dodecyl sulphate by washing with distilled water at least five times; the fraction was then frozen and dried in vacuo over $\mathrm{P}_{2} \mathrm{O}_{5}$.

\section{Analytical methods}

Sodium dodecyl sulphate was estimated spectrophotometrically by the method of Graham \& Whitney (1959).

Paper chromatography was used to determine the amino acids and amino sugars present in acid-hydrolysed cell walls and mucopeptide fractions. Hydrolysis was. done in sealed tubes with $6 \mathrm{~N}-\mathrm{HCl}$ at $105^{\circ}$ for $18 \mathrm{hr}$; subsequently the $\mathrm{HCl}$ was. removed in vacuo over solid $\mathrm{NaOH}$ and $\mathrm{P}_{2} \mathrm{O}_{5}$ at $37^{\circ}$, and the dried residue dissolved in distilled water. Single-dimensional descending chromatography on Whatman no. 4 paper was done with the following solvent systems : (A) $n$-butanol + aceticacid + water $(12+3+5$, by vol. $)$; (B) $n$-butanol + pyridine + water + acetic acid $(60+40+$ $30+3$, by vol.; Primosigh, Pelzer, Maass \& Weidel, 1961); (C) methanol + water + $10 \mathrm{~N}-\mathrm{HCl}+$ pyridine $(80+17 \cdot 5+2 \cdot 5+10$, by vol.; Rhuland, Work, Denman \& Hoare, 1955). Two-dimensional ascending chromatography was done on Whatman no. 1 paper with methanol + water + pyridine $(80+20+4$, by vol.) as the first. solvent and tert.-butanol + methylethylketone + water + diethylamine $(40+40+$ 
$20+4$, by vol.) as the second solvent (Redfield, 1953). Amino acids and amino sugars were detected by spraying with ninhydrin $(0 \cdot 2 \%, w / v$, in acetone) and heating at $100^{\circ}$ for $3 \mathrm{~min}$. Amino sugars were confirmed with a modified Elson-Morgan reagent (Smith, 1958) and alkaline silver nitrate (Smith, 1958).

Isomers of diaminopimelic acid were identified by chromatography in solvent $\mathrm{C}$ (Rhuland et al. 1955), and by the growth response of Escherichia coli 173-25 to the diaminopimelic acid contained in discs cut from unstained strips of chromatograms developed with solvent $\mathbf{A}$.

Total lipid was determined by ether extraction of cell-wall preparations after hydrolysis in $6 \mathrm{~N}-\mathrm{HCl}$ for $4 \mathrm{hr}$ at $100^{\circ}$ (Salton, 1953).

\section{RESULTS}

In addition to the cell walls of the seven species of Gram-negative cocci, we also examined, for reference purposes, the cell walls of three species of Gram-positive cocci and a typical Gram-negative bacterium.

The mucopeptide content for each of the eleven species of bacteria is shown in Table 1. The walls of the six species of Neisseria gave an average mucopeptide yield of $6.9 \%$; a value very close to that obtained for the Escherichia coli cL 30 . In comparison, Veillonella parvula cell walls contained $24.5 \%$ mucopeptide, that is about 3.5 times more than the other Gram-negative bacteria; nevertheless, this corresponded to only about one-third of the amount found in the three Grampositive cocci. (The estimate of $24.5 \%$ mucopeptide in cell walls of $V$. parvula was obtained by pooling the results of two independent experiments which gave $23.1 \%$ and $26 \cdot 4 \%$ mucopeptide, respectively; a total of $143.4 \mathrm{mg}$. dry weight cell wall were analysed.) However, there are two possible sources of error in the determination of the proportion of mucopeptide in the cell wall: (i) adsorption of sodium dodecyl sulphate on to the mucopeptide (Putnam, 1948); (ii) loss of mucopeptide during the repeated washings following sodium dodecyl sulphate treatment of cell walls. Examination of cell walls of Micrococcus lysodeikticus following sodium dodecyl sulphate treatment and subsequent washings revealed no detectable (less than $0.5 \%$ ) bound sodium dodecyl sulphate; on the other hand, an incubation and washing régime equivalent to that used for the isolation of mucopeptide but, with the sodium dodecyl sulphate omitted, resulted in losses of up to $15 \%$ of cell-wall preparations of Neisseria animalis, N. caviae and Staphylococcus saprophyticus. Thus, because of losses during washing, our estimates for the proportion of mucopeptide in cell walls are probably less than the true values.

Chromatography of acid hydrolysates of cell walls of Veillonella parvula, the six Neisseria species and of Escherichia coli showed the following amino acids and amino sugars: diaminopimelic acid, arginine, lysine, aspartic acid, glutamic acid, histidine (trace), glycine, serine, alanine, proline, tyrosine, valine, methionine (trace), isoleucine, leucine, phenylalanine, threonine, muramic acid, glucosamine (see Table 1). Cell walls of $V$. parvula also contained an unidentified ninhydrinreacting constituent; this material, like diaminopimelic acid, was not always obvious in chromatograms of cell-wall hydrolysates because of its relatively low concentration. The mucopeptide isolated from cell walls of the six Neisseria species and of Escherichia coli contained diaminopimelic acid, alanine, glutamic 


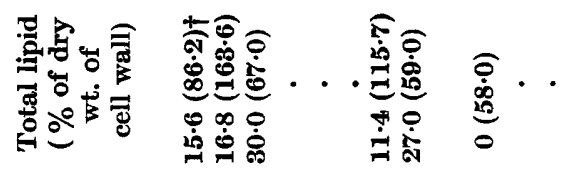

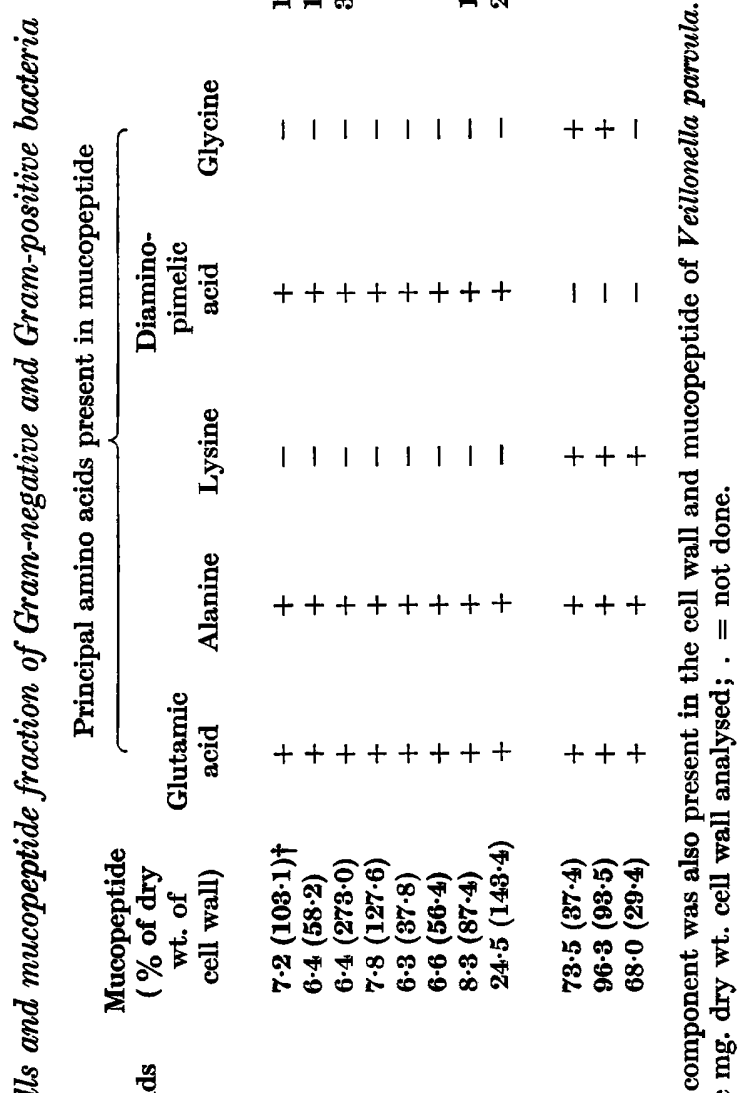

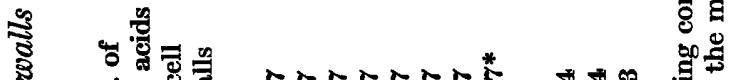

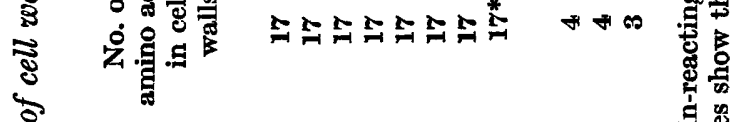

है

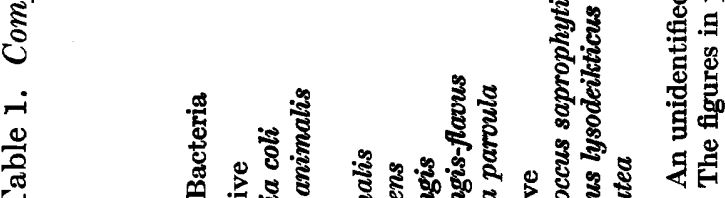


acid, muramic acid and glucosamine as principal components (see Table 1); all other amino acids were either absent or present only in trace amounts. In addition to the amino acids and amino sugars found in the mucopeptide of $E$. coli and the neisserias, $V$. parvula also contained the previously mentioned unidentified ninhydrin-reacting component now present in relatively high concentration. The unknown component formed a single spot in single-dimensional chromatograms, but in the two-dimensional system, although it remained as a single spot at the origin after development with the first solvent, two spots $\left(R_{F}\right.$ values 0.05 and 0.13 , respectively) were observed with the second solvent.

As expected, treatment with sodium dodecyl sulphate produced no obvious qualitative changes in the composition of the cell walls of the three Gram-positive cocci. The principal components detected in the cell walls of these three cocci were lysine, glutamic acid, alanine, muramic acid and glucosamine; the walls of Staphylococcus saprophyticus and Micrococcus lysodeikticus also contained glycine (see Table 1), and there were trace amounts of serine and phenylalanine in $S$. saprophyticus.

The diaminopimelic acid from Veillonella parvula and all six Neisseria species showed an $\boldsymbol{R}_{F}$ value corresponding to the DL or DD isomers in chromatograms developed with solvent $\mathrm{C}$ and permitted the growth of Escherichia coli 173-25. This indicated the presence of the DL isomer in the walls of all seven Gram-negative cocci examined.

All four species of Gram-negative cocci examined contained considerable amounts of lipid (Table 1): Neisseria caviae and Veillonella parvula cell walls contained about twice the amount present in cell walls of Escherichia coli and the other two neisserias. No lipid was detected in the cell walls of Staphylococcus saprophyticus.

\section{DISCUSSION}

In general, the cell walls of Gram-positive bacteria are characterized by a high proportion of mucopeptide, the presence of a few amino acids, and a low lipid content; in addition, the majority of such members of the family Micrococcaceae as have been examined contain lysine (and no diaminopimelic acid) and glycine as principal components of the cell-wall mucopeptide. On the other hand, the cell walls of Gram-negative bacteria contain a small amount of mucopeptide, a wide range of amino acids, and a substantial amount of lipid (see Salton, 1960; Perkins, 1963). In respect of the foregoing criteria, our results for Escherichia coli and the three species of Gram-positive cocci examined agree with previously published data, except that we were unable to detect glycine in the mucopeptide of the Sarcina lutea (Weidel, Frank \& Martin, 1960; Perkins, 1963). Further, the cell walls of the six Neisseria species in so far as we have examined them, show no affinity with the cell walls of the Gram-positive cocci, but closely resemble those of the Gramnegative bacteria as typified by $\boldsymbol{E}$. coli (see Table 1). Veillonella parvula differed only in having a somewhat higher mucopeptide content, but still well below that commonly found in Gram-positive cocci.

The cell walls of Gram-positive and Gram-negative bacteria are just as distinctive structurally as they are chemically. In thin section, the former exhibit a homogeneous outer layer adhering to the plasma membrane (see Glauert, 1962; Murray, 
1962); on the other hand Gram-negative bacteria, including species of Neisseria and Veillonella, show a corrugated triple-layered membrane overlying what seems to be the rigid layer of the wall (Murray, 1963; Murray, Reyn \& Birch-Andersen, 1963; Bladen \& Mergenhagen, 1964). As a result of the differences in structural organization of the cell walls, the surface of Gram-positive bacteria appears smooth and that of Gram-negative bacteria markedly rugose (Zwillenberg, 1964); the Veillonella species examined by Bladen \& Mergenhagen (1964) showed a rugose surface.

A prominent feature of the sections of the Veillonella examined by Bladen \& Mergenhagen (1964) was the unusually thick (70 $\AA$ ) 'solid membrane' lying between the outer triple-layered membrane and the plasma membrane. If this middle membrane is the rigid mucopeptide layer, as suggested by Bladen \& Mergenhagen, then our finding of at least $25 \%$ mucopeptide in Veillonella cell walls is not surprising. In view of the comparatively lower mucopeptide content of walls of all six Neisseria species a corresponding decrease in the thickness of the rigid layer would be expected. In fact, the rigid layer in Neisseria appears to be $20-30 \AA$ in thickness (Dr R. G. E. Murray, personal communication).

Thus the previously demonstrated structural relationship between the genera Veillonella, and Neisseria and other Gram-negative bacteria is complemented by the chemical data obtained in the present work. This relationship is strengthened by the close affinity of the genus Neisseria to the rod-shaped Gram-negative bacteria shown in the numerical taxonomic survey of Sneath \& Cowan (1958). Collectively, these observations would appear to refute Bisset's proposal for the derivation of the Gramnegative cocci from their Gram-positive counterparts (Bisset, 1959, 1962). Indeed, Veillonella, with a relatively thick rigid layer and the ability under certain conditions to divest itself of its outer triple-layered membrane and so structurally mimic the Gram-positive cocci (Bladen \& Mergenhagen, 1964), could represent a transitional stage in the development of the typically Gram-positive cocci from the typically Gram-negative cocci. Alternatively, the gross morphological resemblance between the Gram-negative and Gram-positive cocci could be the result of convergent evolution rather than direct derivation.

\section{REFERENCES}

Annear, D. I. (1962). Recoveries of bacteria after drying on cellulose fibres. Aust. J. exp. Biol. med. Sci. 40, 1.

BisseT, K. A. (1959). Characters associated with parasitism in Gram-positive bacteria. Nature, Lond. 184, B.A. 29.

Bisset, K. A. (1962). The phylogenetic concept in bacterial taxonomy. In Microbial Classification. Symp. Soc. gen. Microbiol. 12, 361.

Bladen, H. A. \& Mergenhagen, S. E. (1964). Ultrastructure of Veillonella and morphological correlation of an outer membrane with particles associated with endotoxic activity. J. Bact. 88, 1482.

Davis, B. D. (1952). Biosynthetic interrelations of lysine, diaminopimelic acid and threonine in mutants of Escherichia coli. Nature, Lond. 169, 534.

Graham, H. D. \& Whitney, R. McL. (1959). Colorimetric determination of sodium laurylsulphate. Analyt. Chem. 31, 1673.

GlaUert, A. M. (1962). The fine structure of bacteria. Br. med. Bull. 18, 245.

HoAre, D. S. \& Work, E. (1955). The stereoisomers of diaminopimelic acid: their distribution in nature and behaviour towards certain enzyme preparations. Biochem. J. 61, 562. 
KanTorowicz, O. (1951). Shaking apparatus for the aeration of bacterial cultures. J. gen. Microbiol. 5, 276.

Mackie and McCartney's Handbook of Bacteriology (1960), 10th ed., p. 190. Ed. by R. Cruickshank. Edinburgh and London: Livingstone.

Murray, R. G. E. (1962). Fine structure and taxonomy of bacteria. In Microbial Classification. Symp. Soc. gen. Microbiol. 12, 119.

Murray, R. G. E. (1963). On the cell wall structure of Spirillum serpens. Canad. J. Microbiol. 9, 381.

Murray, R. G. E., Reyn, A. \& Birch-Andersen, A. (1963). 'The fine structure of Neisseria and possible implication in classification. Canad. J. publ. Hlth, 54, 46.

Nossal, P. M. (1953). A mechanical cell disintegrator. Aust. J. exp. Biol. med. Sci. 31, 583.

Perkins, H. R. (1963). Chemical structure and biosynthesis of bacterial cell walls. Bact. Rev. 27, 18.

Primosigh, J., Pelzer, H., MaAss, D. \& Weidel, W. (1961). Chemical characterization of mucopeptides released from the $E$. coli $B$ cell wall by enzymic action. Biochim. biophys. Acta, 46, 68.

Putnam, F. W. (1948). The interactions of proteins and synthetic detergents. Advanc. Protein Chem. 4, 79.

Redfield, R. R. (1953). Two dimensional chromatographic systems with high resolving power for amino acids. Biochim. biophys. Acta, 10,344.

Rhuland, L. E., Work, E., Denman, R. F. \& Hoare, D. S. (1955). The behaviour of the isomers of diaminopimelic acid on paper chromatograms. J. Amer. chem. Soc. 77, 4844.

Rogosa, M. (1956). A selective medium for the isolation and enumeration of the Veillonella from the oral cavity. J. Bact. 72, 533.

Salton, M. R. J. (1953). The composition of the cell walls of some Gram-positive and Gram-negative bacteria. Biochim. biophys. Acta, 10, 512.

Salton, M. R. J. (1960). Microbial Cell Walls. New York, London: John Wiley and Sons Inc.

SALton, M. R. J. (1963). The relationship between the nature of the cell wall and the Gram stain. J. gen. Microbiol. 30, 223.

Schocher, A. J., Bayley, S. T. \& Watson, R. W. (1962). Composition of purified mucopeptide from the wall of Aerobacter cloacae. Canad. J. Microbiol. 8, 89.

Sмrтн, I. (1958). Chromatographic Techniques. London: William Heinemann Medical Books Ltd.

Sneath, P. H. A. \& Cowan, S. T. (1958). An electro-taxonomic survey of bacteria. $J$. gen. Microbiol. 19, 551.

Weidel, W., Frank, H. \& Martin, H. H. (1960). The rigid layer of the cell wall of $E$. coli B. J. gen. Microbiol. 22, 158.

ZwillenberG, L. O. (1964). Electron microscopic features of gram-negative and grampositive bacteria embedded in phosphotungstate. Antonie van Leeurvenhoek, 30, 154. 